\title{
The philosophy of work in the Gulag: two views in comparison
}

\author{
Antonio Carluccio* \\ Peoples' Friendship University of Russia, 117198, Moscow, Russia
}

\begin{abstract}
This article is devoted to the topic of work, in the frame of the Soviet labor camp, from the point of view of two leading exponents of the lagernaya literatura: Aleksandr Solzhenitsyn, with his novel One Day in the Life of Ivan Denisovich, and Gustaw Herling-Grudzinski with the memoir A World Apart. Both authors write on the same theme, the life of a prisoner, but the focus on the work activities and the interpretation they give is completely different. The description of the working day, the consequences it makes on the everyday life of the prisoners, the struggle for the food needed for surviving the harsh climatic and detention conditions, and finally the philosophical approach used to represent the forced labor, present relevant differences. This article is meant to analyze those differences through the authors' very own words and literary studies. We start from the very raw information detectable by a thorough reading of the two works, going through a moral analysis of the events narrated. While the core narration happens within the same tragic frame, the conclusions they draw are ultimately different.
\end{abstract}

\section{Introduction}

The topic of work is fundamental, being the main activity in the Soviet labor camps. Both stories are rich in valuable information for the reader in order to imagine how were the work activities under the extreme conditions in which the prisoners were kept. From this point of view the novel One Day in the Life of Ivan Denisovich and the collection of memories $A$ world Apart have many affinities even if they present the working activities in a completely different way.

The Russian novel constitutes a sort of watershed between the previous and subsequent literary works. In the Soviet Union the official recognition of Solzhenitsyn marked a historical step toward De-Stalinization, becoming a major event in the country after Khrushchev's historic speech at the 20th party congress [1] It introduced Solzhenitsyn into the literary scenario and removed the taboo from a previously forbidden theme. This story was written between 1956 and 1958 according to Zhores Medvedev [2], while Solzhenitsyn himself will state in an interview that he wrote the story "in only forty days, less than a month and a half" [3].In any case, the author did not try to publish it before 1961 [1]. In this novel, work is the main theme of the whole story, it represents the central part of the day and the separation line between the morning and the night activities.

*Corresponding author: karluchchio_a@pfur.ru 
On the other hand, in Herling's memoir, work as such constitutes the framework of the narrated events but never becomes the main element of the story. The title, A World Apart, does not refer exclusively to the ideas of imprisonment and isolation that dominate this world. The exclusivity of this world apart is in the rules that reign in it. Here the ten commandments are not only not respected, but their exact opposite becomes the rule, the same human values are altered [4]. The plot is narrated in the first person and the protagonist-narrator corresponds to the author. If on the one hand this memoir can be considered a testimony of Soviet concentration camps, from a strictly literary point of view it is appreciable for its didactic content, since the protagonist experiences the evil caused by the political ideologies of the 20th century [5]. In fact, in addition to providing an account of life in Soviet camps, this book is also set against the background of Polish literature as a work of exceptional value. All that the author sees and hears in the prisons and in the camp of Ercevo is reworked in an artistic manner. He puts his inventory of testimonies in order and makes them true through the voices of his characters and his writing skills [6].

\section{Research method}

This study is focused on the topic of work starting from what the same authors want to convey to the reader. Accordingly, the main sources of research were the original texts. A thorough reading of passages, dialogues and description was made on both works. Reading has been corroborated with the relevant critical literature on both authors in four languages (Russian, English, Italian, Polish) found in university libraries as well as on the main academic research platforms (Scopus, Web of Science, Google Scholar, ResearchGate). The amount of literature on Solzhenitsyn has been found more consistent and variegated, though the articles relevant for this study, where not as much as expected. On HerlingGrudzinski, the critical literature regarding A World Apart was mostly in Polish on paper format. According to our prior research, no attempt to compare both authors has been made to the best of our knowledge. This essay focuses on the characteristics of both works in terms of discrepancies between the two camps, but above all on what concerns the work activities. Finally, a wider analysis on the possible layers of thoughts conveyed by authors are investigated and commented.

\section{Findings}

In Solzhenitsyn's novel, Ivan's team works on the construction of a power plant, about which further details are unknown. However, we know that in his camp there was not only that building site, but the inmates also worked on the construction of the "socialist village" of which the narrator does not provide particular information [7, p.7]. Construction was not the only activity, we know indirectly that there was a factory for the manufacture of fur outside the camp [7, p. 117]. The working day in both stories began at half past five and the duration of the official day was eleven hours [7, p. 5; 8, p. 48], although Shukhov worked "only" for ten [7, p. 48] while Herling could work up to twenty [8, p.43]. Herling does not describe the details of his work in the dockers' brigade at the food supply center except indirectly when he tells the story of "Stalin's murderer". This description is however scarce compared to the one presented by Solzhenitsyn in which the raising of a wall constitutes the central scene of the story. Though the working activities in both camps were different, team system and percentages of production were found in both works. However, our attention should be drawn to the human beings experiencing the forced labor in the Gulag more than on the system itself. How can a man survive forced work, humiliation, harsh climate conditions not losing his dignity? The answer provided by both authors is divergent. 
Ivan is a man who can find his niche of happiness within the tough everyday life of the camp. He manages the art of surviving, independently from the obstacle encountered on his way, he tries to face them in order to achieve a benefit and the respect of his fellow workers. In some way the author complies with the writer's duty reported by the II AllUnion Congress of Soviet Writers in 1954: "To create true art, the art of great thoughts and feelings, deeply revealing the rich inner world of the Soviet people, and to embody all the diversity of their work in the characters of their heroes" [9, p. 8]. Every part of this statement may be found in Solzhenitsyn's novel, where Ivan Denisovich, in his specific manner is a sort of Soviet hero, from the intimate, inner world, to his behavior and work activities. However, Ivan may be seen as anti-hero as well, being part of the "little people", whose heroism is given by the unbroken human dignity [1].

Moreover, there are some specific studies on the names given to the characters, which may be seen as a key of interpretation of the main characters. As some scholars claim, the surname Shukhov, given to Ivan Denisovich, may come from the word shukh, shuga-ice, fat, bacon [10]. However, a more suitable interpretation may be the expression of Russian jargon, shukhovat', which means to pick up secretly small advantages for oneself [10]. From this point of view, we may consider Ivan as an anti-hero, who reflects in his name and behavior the invulnerable core of human dignity in a world where people are deprived from time, food, and liberty. The inhuman conditions of the camp are not entirely conveyed by Solzhenitsyn to the reader, as appears in Herling's memoir. The brutalized life does not hinder Ivan to be focused on his work, his stoic approach to what is happening around allows him not to become "less human" [11]. Such view permits to judge positively the working day, without paying attention to what is "rotten" in the system. The Soviet state has punished him for having survived the Nazi camp, accused of being a spy, and charged with 10 years of prison, but Shukhov does not express hate for the state, at least we cannot find this trait in his behavior or his thoughts. He does not become as brutal as the State that has punished him [11], he preserves his core attributes. Shukhov's approach to reality is not far from Sartre's. In his essay "Existentialism is a Humanism", he states that the "existence precedes the essence" [11], therefore, Shukhov does judge the reality in which he lives from the lens of his innermost reality. The camp is not judged as a place of torment, suffering and exploitation, he has no forces or willingness to make such conclusion. Ivan is a peasant, not a philosopher, his pragmatism makes him concentrated on his work, on the orders of the brigade leader and on the expedients to get some extra benefits.

Even though there is much to say on the physical and psychological process of destruction of dignity during the NKVD trials, Ivan does not report the suffering connected with the process of becoming a prisoner. On this topic there is very little information in the novel, though the author made a thoroughly description in The Gulag Archipelago [12]. Taking into account the lack of information given on the past experiences of the protagonist, we may suggest that he is a tempered zek, he accepts the life he is living with courage and psychological strength, without longing for the world outside. According to some scholars, there are deeper layers in this novel: the Christian belief of resurrection of the soul through the sacrifice of the body [13] the superficial, sensorial experience needed to describe the prisoners' conditions [14], the prisoners' absorption in food as a representation of their search for a national identity [15]. Last thesis is of particular interest because in the camp food does not mean just satisfaction of a physical necessity, but represents the only free time the prisoner could enjoy, hence the parallelism between food and freedom. Food is the mean through which free time is acquired, under this perspective work becomes acceptable. The search for warmth and bread is an omnipresent topic, it follows a path parallel to the struggle for surviving. However, the moral integrity of Shukhov toward his companions shows the futility of food and home when a man has lost his dignity [16]. Another interpretation layer is the punishment of an innocent. Ivan 
reaffirms his innocence through conversations on aesthetics with Buinovskii, when they discuss about the tsarist guards in the Ejzenshtein's movie Battleship Potemkin, he knows that those soldiers are not guilty of being "enemies of the people", as well as he is not a Nazi spy [17]. Thus, Ivan shows interest in art, and, even if he has no mean of expressing his conception of aesthetics freely, he conveys his creativity through the work he does [18]. The same expression of art is in his very own way of living, the everyday fight against hunger and cold and the search of perfection in the wall he builds.

For Herling, in this world apart where the most basic rules of civil society are altered, work is synonymous with suffering and exploitation. Only those who have experienced the everyday life of the camp on their skin can understand all the negative feelings and fears that accompany the phrase: "Tomorrow we go back to work" [8, p.147]. A phrase that beyond the barbed wire, although pronounced with a note of fatigue, refers to an activity that is a source well-being. Herling does not accept the realia he lives in because he cannot see any glimmer of hope given by a major effort on the work activity. Though his condition is privileged compared to the majority of inmates of the camp, being a Stakhanovite he receives a richer food ration, the focus of the author is on the destructive philosophy of the labor system in Soviet Union. His fellow prisoners are humiliated, reduced to a bestial state and eventually leaded to death. From the very title we may catch the focus of the author on what makes this world different from the one he lived in before, where encyclopedic description are accompanied with macabre pictures of rat-liked people consumed by work and hunger. Accordingly, work cannot be the right way to freedom, but an accelerated way to death, though indispensable to be given a slightly richer meal. The only hopeful exit from the world apart is rebellion, or better, fighting to claim his own rights, even if it means crushing the logics of the camp itself. Who would like to suffer further starving in a world where people fight to lick the empty cups? Going through the edge of madness during the hunger strike, his attempt of rebellion set him free. Nevertheless, we should not forget that he found himself in a privileged position, due to the Sikorski-Mayski agreement of 194, compared to the Soviet citizens who could not claim such rights. Herling finds himself in two advantaged positions, firstly because he was recognized as a foreign citizen detained in a labor camp abroad, secondly being member of a brigade which was entitled with the maximum percentage of production, he was better fed. Consequently, from his position he can report with frightening realism what he sees and hears, writing a literary encyclopedic masterpiece on the utilization of work as an instrument of dehumanization by the ideologies of the XX century.

Ivan Denisovich, on the other hand, has a different view of work. Ivan is passionate about what he does, so much that he does not reflect on his uncomfortable condition. He is a virtuous bricklayer, the temptation to pretend to be sick is replaced by the fervent willingness to do his job, to share the meal with his companions, and to elaborate new stratagems to survive, he is a model of responsibility at work [19]. The moment he builds the wall, his only concern is to do his job excellently without sparing strength or inventiveness. He is an outsider of his kind, while working he seems not to notice that job is a source of fatigue for him and that he is working for the same system that accused him of high treason and unjustly locked up in a labor camp for eight years. His willpower lies in the acceptance of his status of prisoner in forced labor, not having other choice, he must survive within the barbed wire. The construction of the wall is for him the necessary effort to repay the fortune that constantly assists him and to please his foreman, that is why he has the courage to say: "Why the hell is the working day so short?" [7, p.102].

\section{Conclusion}


Beside a national context, the two books can be inscribed in the international literary context as pioneering works on the subject of Soviet labor camps. Both authors, first Herling and then Solzhenitsyn, contributed to unhinging the foundations of the "Soviet dream" in which many Westerners believed. In particular, Herling contributes to the destruction of this myth outside the Soviet Union while Solzhenitsyn from the within. From the reading of each of these two works a different morality emerges.

In Herling's work, suffering plays a dominant role. It is omnipresent, in particular in the physiological and sensorial field. The author manages through paintings at the edge of the macabre to convey to the reader all shades of human pain found in many of the inhabitants of this world apart. The characters represented are united not only by agony but also by disillusionment. Many of them, Kostylev and Natalia L'vovna in the first place, have been betrayed by their own homeland after believing in the ideology at the power, and now live a daily nightmare tormented by their disillusion. Despite the atrocities they face, these men are not yet completely transformed into soulless beasts, but they have still preserved a core of humanity that emerges in the less atrocious contexts of the camp, such as in the hospital or during a day of rest. The labor camp is not a place of martyrdom only for the Polish people but for all peoples subjected to Soviet power. Herling represents many of the nationalities that make up the world apart, a world of incomprehensible misery that becomes the fundamental rule of everyday life. Yet the author does not forget his origins and the history of his people. As a Polish citizen he takes on the suffering of others, bringing them back by the micro-biographies, but at the same time realizing that he is different. Herling-Grudzinski deeply understands the tragedy of being a Russian in the twentieth century [20] and recognizes his privileged position as a foreigner. He embodies the Polish spirit that yearns for freedom and suffers from his condition of slavery, but, at the same time, he is far from expressing any kind of national stereotypes or Russophobia [21]. From the way in which he describes the landscapes, from his observations on the existence and the frequent requests with which he appeals to God, Herling-Grudzinski can also be called a metaphysical writer. At the heart of Herling's metaphysics is the suffering and sad man facing the end, but, at the same time, able to rise above his limits and his instincts to seek the absolute [6]. Herling's religiosity is based precisely on the belief that no totalitarian system can completely annihilate the intrinsic values of man [6]. He acknowledges that the only way out of slavery is voluntary martyrdom, hence decides to undertake a moral struggle against the corrupted system that he does not recognize and despises. His determination leads him to a freedom that does not end in itself, but finds its full realization in the mission of a fighter for the liberation of all peoples from the Nazifascist oppression with the Polish army of General Anders.

On the other hand, Ivan Denisovich Shukhov can be considered an idealized figure of the practical and virile man. He does not lose heart even in the adverse situations that the life of the labor camp puts before him, but he knows how to exploit them to take an advantage. The experience gained over eight years in the Soviet concentration camps allows him to make money from any kind of manual activity. He is constantly busy and willing to roll up his sleeves. From Ivan's thoughts that the narrator conveys to us, we understand how he has assimilated the logic of this institution and how he knows the survival techniques within it. The figure of the Shukhovian hero is worth of admiration and respect since he demonstrates that although a man can be obliged to comply with an inhuman system of living and work, his core dignity may stay unaltered. Ivan is not engaged in animate diatribes on the sense of his condition of convicted innocent, he does not dream about the day he will live the camp but he knows the only way to survive is to accept what is unacceptable maintaining unaltered his selfhood before the horrors he experiences. From his approach to job, work becomes the only instrument of salvation, as well as the unique sensible choice to acquire a piece of freedom. He may be seen as an 
expression of the Russian people, who despite suffering for centuries the abuses of the regime at the power, accepted the harsh reality of life and tried at the best of their forces to acquire the means necessary for stability and self-realization.

\section{Acknowledgements}

To my Father.

The publication has been prepared with the support of the "RUDN University Program 5$100 "$.

\section{References}

1. M. A. Arias-Vikhil'a, T. V. Marchenkob, D. S. Moskovskaya, "The Truth That the Reader So Longed for" On the 100th Anniversary of the Birth of Academician A.I. Solzhenitsyn, Herald of the Russian Academy of Sciences, 88 (6),521-530 (2018)

2. Zh. A. Medved, Dieci anni dopo Ivan Denisovič (Mondadori, Milano, 1974)

3. L. I. Saraskina, Aleksandr Solženicyn (Molodaja Gvardija, Moskva 2008)

4. W. Bolecki, „Inny Świat” Gustawa Herlinga-Grudzińskiego (Biblioteka Analiz Literackich, Warszawa 1994)

5. Literatura polska XX wieku. Przewodnik encyklopedyczny (Wydawnictwo Naukowe PWN, Warsawa, 2000)

6. Z. Kudelski, Studia o Herlingu-Grudzińskim (Towarzystwo Naukowe Katolickiego Uniwersytetu Lubelskiego, Lublin, 1998).

7. A. Solzhenitsyn, Una giornata di Ivan Denisovich (Einaudi, Torino 1999)

8. G. Herling-Grudzinski, Un mondo a parte (Feltrinelli, Milano,2010)

9. II All-Union Congress of Soviet Writers. (December 15-26, 1954), Verbatim Report Moscow: Sovietskii Pisatel'.

10. E. Ruttner, The Names in Solzhenitsyn's Short Novel: One Day in the Life of Ivan Denisovich, Names, 23(2), 103-111 (1975).

11. A. Radhakrishnan, THE SHADOW OF TRUTH Ethical Concerns in the Writings of Alexander Solzhenitsyn, Journal of Dharma, 38 (3), 269-28 (2013)

12. B. Fekete, The Dream of Western Law. Legal Layers in Solzhenitsyn's Gulag Archipelag, Acta Juridica Hungarica, 53 (1),72-82 (2012).

13. R. Yarup, Solzhenitsyn's One Day in the Life of Ivan Denisovich, The Explicator, 45, 53-55 (1986).

14. R. Yarup, Solzhenitsyn's One Day in the Life of Ivan Denisovich, The Explicator, 40, 61-63 (1984).

15. D. Xu, Food and Homecoming in Solzhenitsyn's One Day in the Life of Ivan Denisovich, The Explicator, 66, 104-108 (2008).

16. R. Hauhart, Bread and Warmth in One Day in the Life of Ivan Denisovich, The Explicator, 68 (3), 203-206 (2010).

17. R. Salys, Solzhenitsyn's One Day in the Life of Ivan Denisovich, The Explicator, 64 (2), 112-115 (2006).

18. A. Klimoff, The Sober Eye: Ivan Denisovich and the Peasant Perspective. One Day in the Life of Ivan Denisovich. A Critical Companion, Evanston, IL, NorthwesternUP, 331 (1997).

19. A. McKie, One Day in the life of Ivan Denisovich (1962): Alexander Solzhenitsyn, Nurse Education Today, 31, 539-540 (2011).

20. M. Gloger, Rosyjski Arlekin i Nierozpoznanym Motywie w "Jądrze Ciemności" i o Rosji Josepha Conrada (Prolegomena do kultury rosjiskiej), Pamietnik Literacki, 105 (1), 7-24. (in Polish) (2014).

21. A. Nasilovskaya, Lagernaya Moral'- tri pol'skie knigi o lageryakh: B. Obretynskaya, 
B. Skarga, G. Herling-Grudzinski. In Rossiya-Pol'sha Obrazy i Stereotipy v Literature i Kul'ture (Indrik, Moskva, 2002). 